\title{
Elemental and Radioactivity Concentration of Stream Sediments in Abu-Rusheid, Nugrus Area - South Eastern Desert, Egypt
}

\author{
S.U. El-kameesy ${ }^{1}$, S.Y. Afifi ${ }^{2}$, A. Hamid ${ }^{3}$, Ali Ajeeb ${ }^{1, *}$ \\ ${ }^{1}$ Department of Physics, Faculty of Science, Ain Shams University, Cairo, Egypt \\ ${ }^{2}$ Nuclear Materials Authority (NMA), Cairo, Egypt \\ ${ }^{3}$ Radiated Pollution Department, Hot Laboratories Center, Atomic Energy Authority, Egypt \\ Email address: \\ ali_ajeeb@yahoo.com (A. Ajeeb)
}

\section{To cite this article:}

S.U. El-kameesy, S.Y. Afifi, A. Hamid, Ali Ajeeb. Elemental and Radioactivity Concentration of Stream Sediments in Abu-Rusheid, Nugrus Area - South Eastern Desert, Egypt. American Journal of Physics and Applications. Vol. 3, No. 6, 2015, pp. 183-189.

doi: 10.11648/j.ajpa.20150306.11

\begin{abstract}
As a part of the national survey to evaluate some strategic elements such as $\mathrm{U}, \mathrm{Mn}, \mathrm{Fe}$ and $\mathrm{Cu}$ we have undertaken a quantitative study to fulfill this target. Twenty sediment samples were collected from Abu Rusheid Area in South Eastern desert of Egypt. The concentrations of radium-226 and thorium-232 were determined by direct counting using a hyper pure germanium (HPGe) detector interfaced with a multi-channel analyzer (MCA) . The obtained results showed that the specific activity of ${ }^{226} \mathrm{Ra}$ ranged from $65.71 \pm 16$ to $208.2 \pm 20 \mathrm{~Bq} / \mathrm{kg}$ and ${ }^{232} \mathrm{Th}$ from $27.14 \pm 8.69$ to $206.89 \pm 40.1 \mathrm{~Bq} / \mathrm{kg}$ while ${ }^{40} \mathrm{~K}$ from 127.73 to $443.84 \mathrm{~Bq} / \mathrm{kg}$. These values are higher than the international recommended levels. The radium equivalent activity $\left(\mathrm{Ra}_{\mathrm{eq}}\right)$, the absorbed dose rate (D), the external hazard index (Hex), the annual effective dose equivalent (AEDE) and the representative level index (I $\gamma \mathrm{r})$ were also calculated and compared with the international recommended values. Additionally, $\mathrm{X}$-ray fluorescence analysis for soil sample has been performed and considerable concentrations of $\mathrm{Al}, \mathrm{Fe}, \mathrm{Mn}$ and $\mathrm{Zn}$ has been found.
\end{abstract}

Keywords: ${ }^{226} \mathrm{Ra},{ }^{232} \mathrm{Th},{ }^{40} \mathrm{~K}$, Norm, South Eastern, Absorbed Dose Rates, Radium Equivalent Activity, External Hazard Index

\section{Introduction}

It is very well- known that every living creature is exposed to ionizing radiation. This radiation is a part of the earth and comes from cosmos and affects all the goods, food and even the air that we breathe and makes them partially radioactive. So, human beings are exposed to natural background radiation every day from the ground, building materials, air, food, the universe, and even elements in their own bodies[1].

The terrestrial component of the natural background is dependent on the compositions of the soils and rocks containing natural radionuclides. The radioactivity of soils is essential for understanding changes in the natural radiation background [2, 3]. Soil contains small quantities of radioactive elements $\mathrm{Ra}$ and $\mathrm{Th}$ along with their progenies. The natural radioactivity of soil and sediment depends on the soil and sediment formation and transport processes that were involved since soil and sediment formation; chemical and biochemical interactions influence the distribution patterns of uranium, thorium and their decay products [4].

$\mathrm{Abu}$ Rusheid Area in South Eastern desert of Egypt is located between a major thrust to the NE and a minor one to the SW. The stream sediments along Nugrus area are formed due to the weathering processes of the different surrounding rocks. These rocks are almost of granitic origin. Granitic rocks have relatively high concentration of the members of the natural radioactive series of ${ }^{238} \mathrm{U},{ }^{232} \mathrm{Th}$ and ${ }^{235} \mathrm{U}$. The presence of these naturally occurring radionuclides along with the non-series radionuclide ${ }^{40} \mathrm{~K}$ and their daughter products in building materials is a source of indoor radioactive pollution. Nugrus area is recently subjected to several geological activities to explore precious minerals such as gold, zirconium and pyrite, etc... This reflects the possibility of establishing many development projects at that area [5]. 


\section{Materials and Methods}

\subsection{Sampling and Sample Preparation}

Twenty representative geological samples were collected from Abu Rusheid, Nugrus Area in South Eastern desert of Egypt. The location of this area is clearly shown in Fig (1). All samples were dried at $105^{\circ} \mathrm{C}$ for 24 hours to eliminate water of moisture. The representative powdered samples were placed in polyethylene bottles of $350 \mathrm{~cm}^{3}$. Each sample was sealed from air in a container, whose inner diameter was equal to the diameter of the detector in face to face geometry. Finally, samples were stored for four weeks to reach the equilibrium state between radium and its decay products.

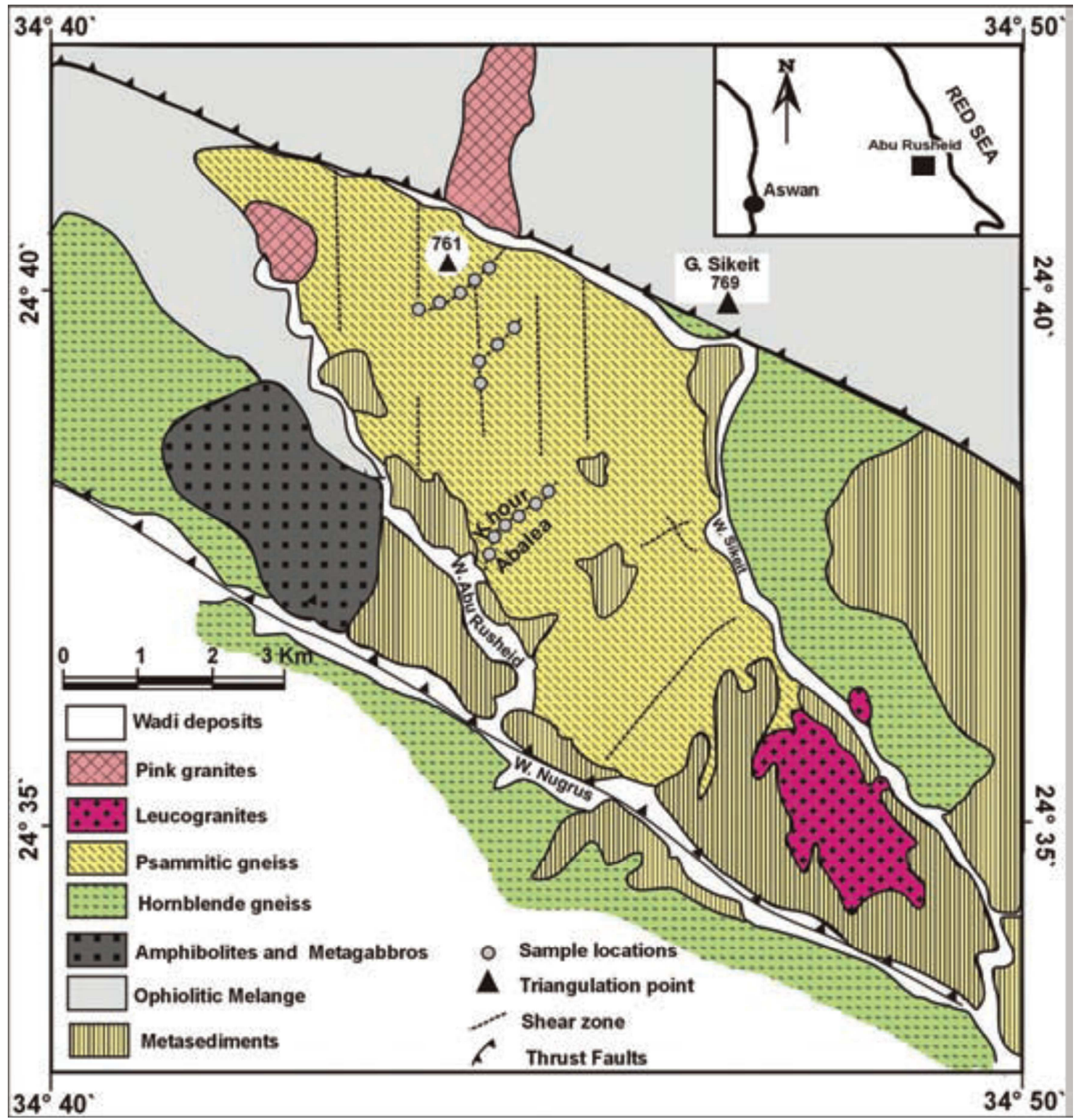

Figure 1. Geological map of the study area showing sample locations.

\subsection{Experimental Techniques (Detection System Set-Up)}

The energy and intensity of various gamma ray lines have been measured using an ORTEC HPGe detector of volume $62.3 \mathrm{cc}$ and relative efficiency $30 \%$ relative to $3 " \mathrm{n} 3$ " $\mathrm{NaI}$ (T1) detector coupled to a 4096 multichannel analyzer. The full width at half maximum (FWHM) was found to be 1.8 $\mathrm{keV}$ for ${ }^{60} \mathrm{Co}-1332 \mathrm{keV} \gamma$-ray line. For accurate energy determination, the spectrometer was calibrated using gamma ray lines of different standard sources. The activity concentration of ${ }^{226} \mathrm{Ra}$ was determined using the 295.1
(19.2\%) and $352(37.1 \%) \mathrm{keV}$ gamma-rays from ${ }^{214} \mathrm{~Pb}$ and the $609.3(46.1 \%)$ and $1120.3(15 \%) \mathrm{keV}$ gamma-rays from ${ }^{214} \mathrm{Bi}$. ${ }^{232} \mathrm{Th}$ activity was determined from the gamma-rays, $238.6(43.6 \%) \mathrm{keV}$ from ${ }^{212} \mathrm{~Pb}, 338.4(12 \%), 911.2(29 \%)$ and $969(17 \%) \mathrm{keV}$ from ${ }^{228} \mathrm{Ac}$ and $583.0(86 \%), 2614(36 \%)$ $\mathrm{keV}$ gamma-rays from ${ }^{208} \mathrm{Tl}$.

\subsection{Description of the X-Ray Fluorescence System}

XRF technology provides one of the simplest, most accurate and most economic analytical methods for the 
determination of the chemical composition of many types of materials. It is non-destructive and reliable, requires no, or very little, sample preparation and is suitable for solid, liquid and powdered samples [6].

In this study, the XRF technique was used to determine the trace element contents using PHILIPS X'Unique-II spectrometer with automatic sample changer PW 1510, (30 positions). This instrument is connected to a computer system using X-40 program. The trace elements concentrations are calculated from the program's calibration curves which were set up according to international reference materials, (standards), as NIM-G, G-2, GSP-1, AGV-1, JB-1 and NIM-D [7].

The trace elements were measured by calibrating the system under the conditions of Rh-target tube, LiF-420 crystal, gas flow proportional counter, (GFPC), coarse collimators, vacuum, $30 \mathrm{kV}$ and $40 \mathrm{~mA}$ for the determination of $\mathrm{V}, \mathrm{Cr}, \mathrm{Co}, \mathrm{Ni}, \mathrm{Cu}, \mathrm{Zn}$ and $\mathrm{Ga}, 70 \mathrm{kV}$ and $15 \mathrm{~mA}$, for $\mathrm{Rb}$, $\mathrm{Sr}, \mathrm{Y}, \mathrm{Zr}$ and $\mathrm{Nb}$ and $100 \mathrm{kV}$ and $10 \mathrm{~mA}$ for the determination of $\mathrm{Ba}$ and $\mathrm{Pb}$. The detection limit is the lowest concentration, and it is a function of the level of background noise relative to an element signal. The detection limit for the elements measured by XRF technique is estimated at $2 \mathrm{ppm}$ for $\mathrm{Rb}, \mathrm{Nb}, \mathrm{Ga}, \mathrm{Co}, \mathrm{Y}$ and $\mathrm{Sr}$ and at $8 \mathrm{ppm}$ for $\mathrm{Pb}$ and $\mathrm{Cu}$ and 5 ppm for other measured trace elements.

\subsection{Sample Preparation for X-Ray Fluorescence}

A total of 5 samples were completely analyzed using Xray fluorescence, these samples were collected from $\mathrm{Abu}$ Rusheid, Nugrus Area in Eastern Desert of Egypt. For trace element analysis, pressed powder pellets were prepared by filling an alumina cup, (diameter $4 \mathrm{~cm}$, height $1.2 \mathrm{~cm}$ and weight $3 \mathrm{gm}$ ), with $9 \mathrm{gm}$ of crystalline boric acid covered by $1 \mathrm{gm}$ of the grounded sample, ( 200 mesh grain size), and then pressed under $12 \mathrm{t}$ using semi-automatic hydraulic press model HERZOG HTP-40.

\subsection{Calculation of Radioactivity Concentration}

The specific activity (in $\mathrm{Bq} \cdot \mathrm{kg}^{-1}$ ) is given by [8]:

$$
\mathrm{A}=\frac{N P}{t_{c} \cdot I_{\gamma}\left(E_{\gamma}\right) \cdot \varepsilon\left(E_{\gamma}\right) \cdot M}
$$

where NP is the net number of counts in a given peak area at energy $\mathrm{E}, \varepsilon\left(E_{\gamma}\right)$ the detection efficiency at energy $\mathrm{E}, \mathrm{t}_{\mathrm{c}}$ is the counting time in seconds, $I_{\gamma}\left(E_{\gamma}\right)$ the number of gammas per disintegration of this nuclide for a transition at energy $E$, and $\mathrm{M}$ is the mass in $\mathrm{kg}$ of the measured sample.

\section{Results and Discussion}

\subsection{Radioactivity Concentrations}

The activity concentrations of the radionuclides ${ }^{232} \mathrm{Th}$, ${ }^{226} \mathrm{Ra}$ and ${ }^{40} \mathrm{~K}$ in the collected samples, considered in the present study are presented in Table (1) and illustrated in Fig (2). The values are given in $\mathrm{Bq} / \mathrm{Kg}$ on a dry weight basis. The minimum and maximum along with the average values of the activity concentrations of the radionuclides are given in Table (2).The activity concentration of ${ }^{232} \mathrm{Th}$ ranged from 27.14 to 206.89 Bq/ $\mathrm{kg}$ with an average value $83.51 \mathrm{~Bq} / \mathrm{kg}$, which is higher than the international radioactivity average level (50 $\mathrm{Bq} / \mathrm{kg}$ ). The ${ }^{226} \mathrm{Ra}$ activity concentration ranged from 65.71 to $208.23 \mathrm{~Bq} / \mathrm{kg}$ with an average $120.23 \mathrm{~Bq} / \mathrm{kg}$, which is higher than the average values of the international recommended levels $(35 \mathrm{~Bq} / \mathrm{kg})$ [9]. For ${ }^{40} \mathrm{~K}$, the average value is $299.082 \mathrm{~Bq} / \mathrm{kg}$, which is lower than the international average radioactivity levels $(500 \mathrm{~Bq} / \mathrm{kg})$.

Fig 3 illustrates the correlation between the activity concentrations of ${ }^{226} \mathrm{Ra}$ and ${ }^{232} \mathrm{Th}$. From that Figure It can be seen that there is a satisfactory correlation between ${ }^{226} \mathrm{Ra}$ and ${ }^{232} \mathrm{Th}$ with a correlation coefficient of 0.76 . According to Tzortzis and Al-Hamarneh [10,11], the theoretical values of the elemental ratios of $\mathrm{Th} / \mathrm{Ra}$ are expected to be approximately 3.0 for normal continental crust. In the current study, the obtained results of the elemental ratios for $\mathrm{Th} / \mathrm{Ra}$ varies from 0.413 to 1.104 . The small value of the $\mathrm{Th} / \mathrm{Ra}$ ratios may be attributed to a reduction of ${ }^{232} \mathrm{Th}$ or an increase of ${ }^{226} \mathrm{Ra}$ due to the alteration or natural processes in that area.

Table 1. The calculated specific activities (Bq/kg) for ${ }^{232} \mathrm{Th},{ }^{226} \mathrm{Ra}$, and ${ }^{40} \mathrm{~K}$ along with the ratio ${ }^{232} \mathrm{Th}^{226} \mathrm{Ra}$ in the investigated region.

\begin{tabular}{lllll}
\hline Sample & ${ }^{232} \mathbf{T h}$ & ${ }^{226} \mathbf{R a}$ & ${ }^{40} \mathbf{K}$ & ${ }^{232} \mathbf{T h} /{ }^{2 \mathbf{2 6}} \mathbf{R}$ \\
\hline Sh-1 & $27.14 \pm 8.69$ & $65.71 \pm 16$ & 225.97 & 0.413 \\
Sh-2 & $46.08 \pm 14.58$ & $68.92 \pm 9.39$ & 214.59 & 0.669 \\
Sh-3 & $53.08 \pm 22.68$ & $103.90 \pm 8.25$ & 275.29 & 0.511 \\
Sh-4 & $48.83 \pm 18.46$ & $81.82 \pm 7.29$ & 287.01 & 0.597 \\
Sh-5 & $53.85 \pm 15.88$ & $106.29 \pm 12.79$ & 359.39 & 0.507 \\
Sh-6 & $58.49 \pm 21.49$ & $128.54 \pm 18.9$ & 401.87 & 0.455 \\
Sh-7 & $56.54 \pm 15.25$ & $106.45 \pm 15.97$ & 363.53 & 0.531 \\
Sh-8 & $54.16 \pm 12.64$ & $101.11 \pm 15.39$ & 374.82 & 0.536 \\
Sh-9 & $80.31 \pm 24.12$ & $138.43 \pm 17.70$ & 443.84 & 0.580 \\
Sh-10 & $69.44 \pm 20.29$ & $115.97 \pm 14.45$ & 365.05 & 0.599 \\
Sh-11 & $182.53 \pm 58.14$ & $180.77 \pm 30.09$ & 176.13 & 1.010 \\
Sh-12 & $70.60 \pm 26.99$ & $129.67 \pm 14.57$ & 403.24 & 0.544 \\
Sh-13 & $96.22 \pm 39.66$ & $109.75 \pm 21.56$ & 127.73 & 0.877 \\
Sh-14 & $66.68 \pm 13.01$ & $81.83 \pm 8.03$ & 215.59 & 0.815 \\
Sh-15 & $76.18 \pm 13.77$ & $128.39 \pm 11.80$ & 360.01 & 0.593 \\
Sh-16 & $77.83 \pm 14.25$ & $133.73 \pm 14.7$ & 364.4 & 0.582 \\
Sh-17 & $114.42 \pm 22.01$ & $165.04 \pm 15.70$ & 440.01 & 0.693 \\
Sh-18 & $206.89 \pm 40.01$ & $208.23 \pm 20.09$ & 180.13 & 0.994 \\
Sh-19 & $145.74 \pm 30.65$ & $132.01 \pm 18.65$ & 129.03 & 1.104 \\
Sh-20 & $85.12 \pm 20.3$ & $118.13 \pm 9.03$ & 274.01 & 0.721 \\
\hline
\end{tabular}

Table 2. Minimum, maximum and average activity concentration values for ${ }^{232} \mathrm{Th}^{226} \mathrm{Ra},{ }^{40} \mathrm{~K}$ and ${ }^{232} \mathrm{Th}^{226} \mathrm{Ra}$.

\begin{tabular}{llll}
\hline nuclide & Minimum & maximum & Average \\
\hline${ }^{232} \mathrm{Th}$ & $27.14 \pm 8.69$ & $206.89 \pm 40.01$ & 83.51 \\
${ }^{226} \mathrm{Ra}$ & $65.71 \pm 16$ & $208.23 \pm 20.09$ & 120.23 \\
${ }^{40} \mathrm{~K}$ & 127.73 & 443.84 & 299.082 \\
$\mathrm{Th} / \mathrm{Ra}$ & 0.413 & 1.104 & 0.666 \\
\hline
\end{tabular}




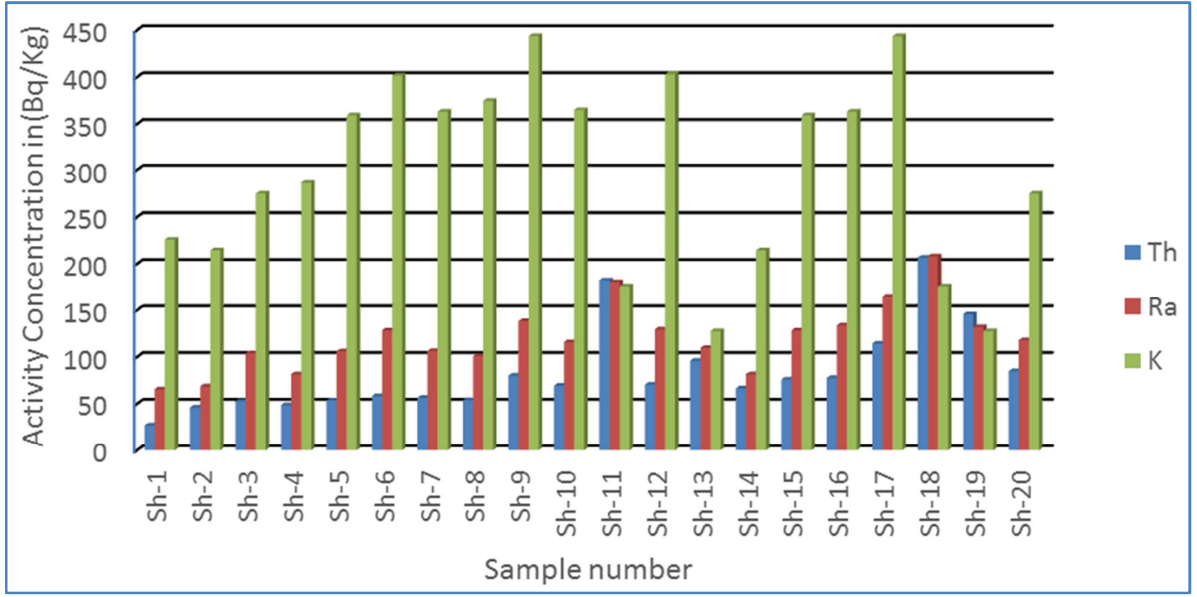

Figure 2. The activity concentration of radionuclides in the considered samples.

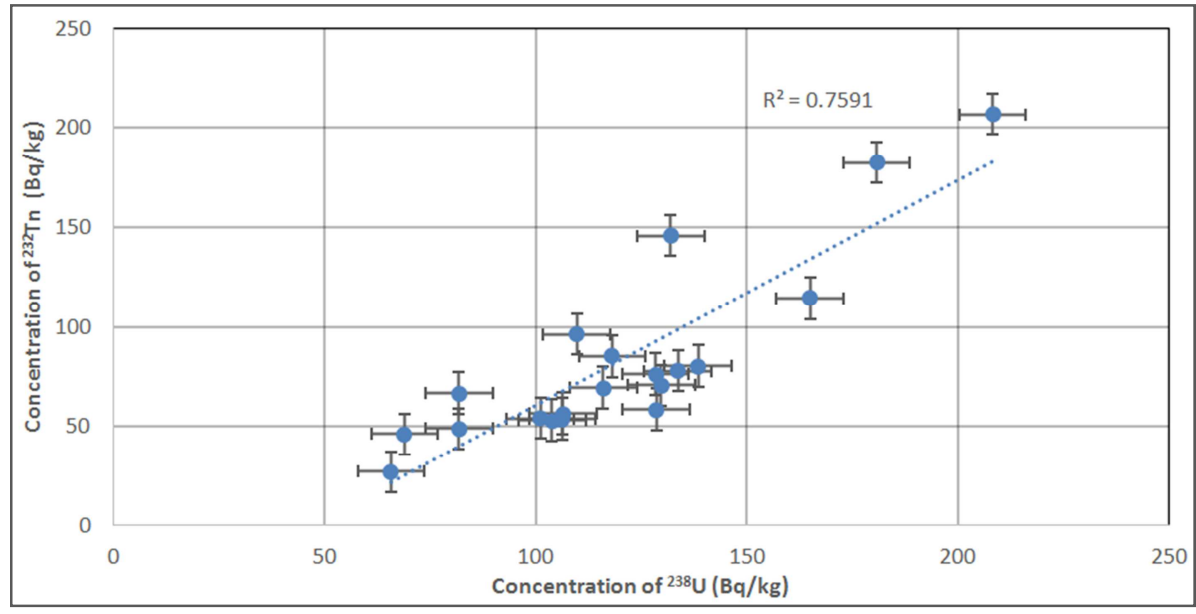

Figure 3. Correlation between ${ }^{226} \mathrm{Ra}$ and ${ }^{232}$ Th activity concentration in all soil samples.

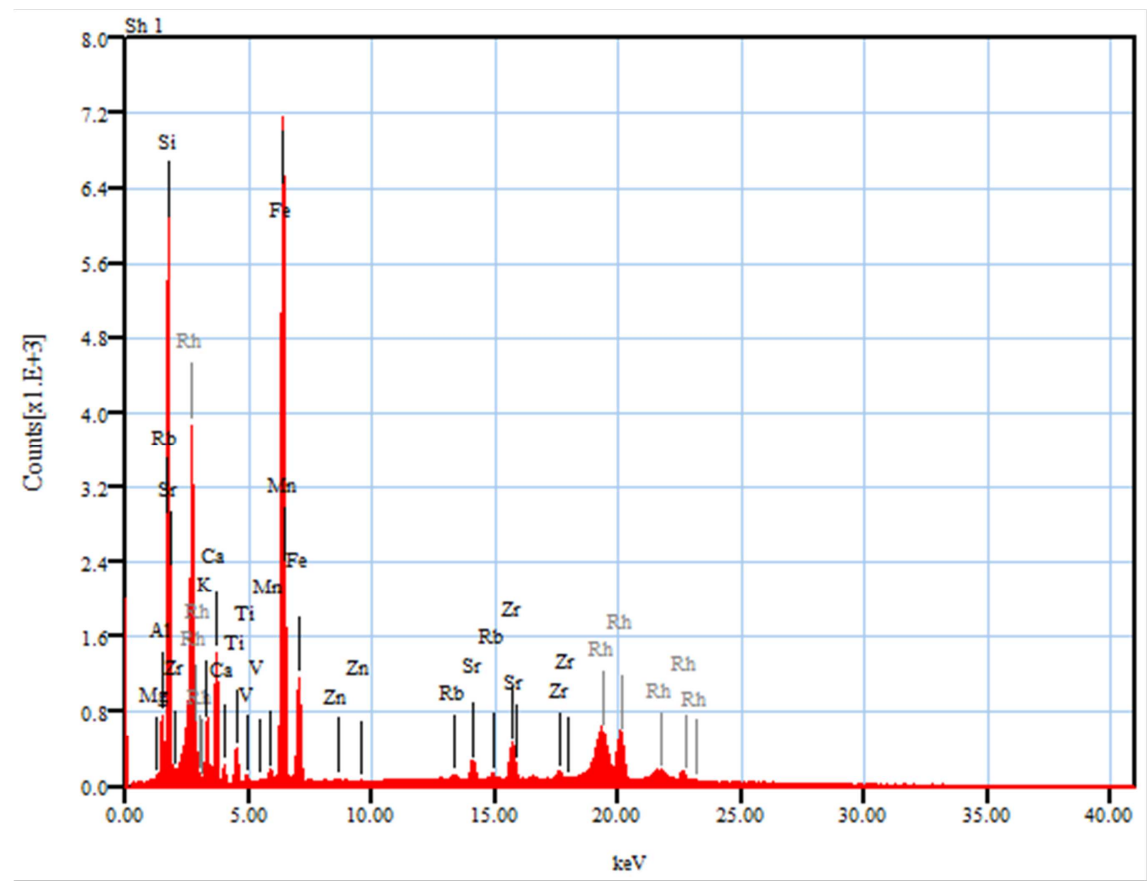

Figure 4. X-ray fluorescence (XRF) spectra of sample sh-1. 


\subsection{The Trace Element Analysis}

According to the XRF results $\mathrm{Mg}, \mathrm{Al}, \mathrm{Fe}$ and $\mathrm{Zn}$ in some samples have remarkable concentration that could be extracted by different suitable methods in order to be used in different important industries. Mg contribution in the samples is ranging from 1.24 to $2.35 \%, \mathrm{Al}$ is ranging from 8.99 to $9.42 \%, \mathrm{Fe}$ is ranging from 12.84 to $18.76 \%$, and $\mathrm{Zn}$ is ranging from $850 \mathrm{ppm}$ to $1720 \mathrm{ppm}$. These values indicate that the rock samples of the place under study can be considered as a production area for the aforementioned elements. The analyzed samples are given in Table (3), and an example of the XRF spectra is displayed in Fig (4).

\subsection{Assessment of Radiological Hazard}

One of the main objectives of the radioactivity measurements in an environmental sample is not simply to determine the activity concentrations of ${ }^{226} \mathrm{Ra},{ }^{232} \mathrm{Th}$ and ${ }^{40} \mathrm{~K}$ but also to estimate the radiation exposure dose and to assess the biological effects on humans. The assessment of radiological risk can be considered in various terms. In the current study, four related quantities were deduced, these are: (i) the absorbed dose rate (D) in air at 1 meter above the ground surface; (ii) the annual effective dose equivalent (AEDE) from outdoor terrestrial gamma radiation; (iii) the radium equivalent activity $\left(\mathrm{Ra}_{\mathrm{eq}}\right)$; and (iv) the external hazard index $\left(\mathrm{H}_{\mathrm{ex}}\right)$. These radiological parameters can be calculated from the measured activity concentrations of three main primordial radionuclides in the soil samples[12].

Table 3. Trace elements concentrations (percent), for the collected samples from Abu Rusheid area, Southeastern Desert of Egypt.

\begin{tabular}{llllll}
\hline Element & Sh-1 & Sh-4 & Sh-8 & Sh-9 & Sh-10 \\
\hline $\mathrm{Mg}$ & 1.24 & 1.61 & 1.68 & 2.35 & 1.412 \\
$\mathrm{AL}$ & 9.27 & 9.42 & 8.99 & 9.18 & 9.415 \\
$\mathrm{Si}$ & 51.356 & 54.08 & 57.01 & 56.43 & 57.18 \\
$\mathrm{~K}$ & 6.27 & 9.29 & 9.8 & 9.21 & 9.35 \\
$\mathrm{Ca}$ & 10.23 & 8.9 & 7.32 & 8.09 & 6.97 \\
$\mathrm{TI}$ & 1.94 & 1.27 & 0.967 & 0.859 & 0.85 \\
$\mathrm{~V}$ & 0.0248 & 0 & 0 & 0 & \\
$\mathrm{Mn}$ & 0.2114 & 0.203 & 0.18 & 0.167 & 0.126 \\
$\mathrm{Fe}$ & 18.76 & 14.29 & 13.2 & 12.84 & 13.78 \\
$\mathrm{Zn}$ & 0.085 & 0.136 & 0.11 & 0.172 & 0.129 \\
$\mathrm{Rb}$ & 0.062 & 0.145 & 0.148 & 0.173 & 0.145 \\
$\mathrm{Sr}$ & 0.187 & 0.103 & 0.09 & 0.08 & 0.079 \\
$\mathrm{Zr}$ & 0.341 & 0.281 & 0.228 & 0.272 & 0.322 \\
$\mathrm{Nb}$ & 0 & 0.052 & 0 & 0.095 & 0.056 \\
$\mathrm{Ru}$ & 0 & 0.153 & 0.086 & 0 & \\
$\mathrm{Cr}$ & 0 & 0 & 0.076 & 0.08 & 0.08 \\
$\mathrm{Ni}$ & 0 & 0 & 0.059 & 0 & \\
$\mathrm{Y}$ & 0 & 0 & 0.05 & 0 & 0.066 \\
$\mathrm{As}$ & 0 & 0 & 0 & 0 & 0.343 \\
\hline
\end{tabular}

\subsubsection{Absorbed Dose Rate in Air (D)}

The absorbed dose rate could be obtained by the following formula [13]:

$$
\mathrm{D}\left(\mathrm{nGy} \cdot \mathrm{h}^{-1}\right)=0.462 \mathrm{~A}_{\mathrm{Ra}}+0.604 \mathrm{~A}_{\mathrm{Th}}+0.0417 \mathrm{~A}_{\mathrm{K}}
$$

Where $\mathrm{D}$ is the absorbed dose rate in $n G y \cdot \mathrm{h}^{-1}, \mathrm{~A}_{\mathrm{Ra}}, \mathrm{A}_{\mathrm{Th}}$ and $\mathrm{A}_{\mathrm{K}}$ are the activity concentrations of ${ }^{226} \mathrm{Ra},{ }^{232} \mathrm{Th}$ and ${ }^{40} \mathrm{~K}$, respectively.

\subsubsection{Annual Effective Dose Equivalent (AEDE)}

The absorbed dose rate in air at 1 meter above the ground surface does not directly provide the radiological risk to which an individual is exposed. The absorbed dose can be considered in terms of the annual effective dose equivalent from outdoor terrestrial gamma radiation which is converted from the absorbed dose by taking into account two factors, namely the conversion coefficient from absorbed dose in air to effective dose and the outdoor occupancy factor. The annual effective dose equivalent can be estimated using the following formula [14]:

$$
\operatorname{AEDE}\left(\mu \mathrm{Sv} \cdot \mathrm{y}^{-1}\right)=\mathrm{D}\left(\mathrm{nGy} \cdot \mathrm{h}^{-1}\right) \times 8760 \mathrm{~h} \text { x } 0.2 \times 0.7 \mathrm{~Sv}^{\mathrm{G}} \mathrm{Gy}^{-1} \times 10^{-3}
$$

Where the values $0.7 \mathrm{~Sv} \mathrm{~Gy}^{-1}$ is taken as the conversion coefficient from absorbed dose in air to effective dose received by adults and 0.2 is the outdoor occupancy factor.

\subsubsection{Radium Equivalent Activity $\left(\boldsymbol{R a}_{e q}\right)$}

Due to a non-uniform distribution of natural radionuclides in the soil samples, the actual activity level of ${ }^{226} \mathrm{Ra},{ }^{232} \mathrm{Th}$ and ${ }^{40} \mathrm{~K}$ in the samples can be evaluated by means of a common radiological index named the radium equivalent activity $\left(\mathrm{Ra}_{\mathrm{eq}}\right)$. It is the most widely used index to assess the radiation hazards. This estimates that $370 \mathrm{~Bq} \cdot \mathrm{kg}^{-1}$ of ${ }^{226} \mathrm{Ra}$, $259 \mathrm{~Bq} \cdot \mathrm{kg}^{-1}$ of ${ }^{232} \mathrm{Th}$ and $4810 \mathrm{~Bq} \cdot \mathrm{kg}^{-1}$ of ${ }^{40} \mathrm{~K}$ produce the same gamma-ray dose rate. Therefore, $\mathrm{Ra}_{\mathrm{eq}}$ can be obtained by the following relation [15]

$$
\mathrm{Ra}_{\mathrm{eq}}\left(\mathrm{Bq} \cdot \mathrm{kg}^{-1}\right)=\mathrm{A}_{\mathrm{Ra}}+1.43 \mathrm{~A}_{\mathrm{Th}}+0.077 \mathrm{~A}_{\mathrm{K}}
$$

Where $A_{R a}, A_{T h}$ and $A_{K}$ are the activity concentration of ${ }^{226} \mathrm{Ra},{ }^{232} \mathrm{Th}$ and ${ }^{40} \mathrm{~K}$ in $\mathrm{Bk} / \mathrm{kg}$ respectively. The permissible maximum value of the radium equivalent activity is 370 Bq. $\mathrm{kg}^{-1}$ which corresponds to an effective dose of $1 \mathrm{mSv}$ for the general public.

\subsubsection{External Hazard Index $\left(H_{e x}\right)$}

To limit the radiation exposure attributable to natural radionuclides in the samples to the permissible dose equivalent limit of $1 \mathrm{mSv} \cdot \mathrm{y}^{-1}$, the external hazard index based on that criterion have been introduced using a model proposed by Krieger (1981) which is given by[16,17].

$$
\mathrm{H}_{\mathrm{ex}}=\mathrm{A}_{\mathrm{Ra}} / 370+\mathrm{A}_{\mathrm{Th}} / 259+\mathrm{A}_{\mathrm{K}} / 4810
$$

Where $A_{R a}, A_{T h}$ and $A_{K}$ are the activity concentration of ${ }^{226} \mathrm{Ra},{ }^{232} \mathrm{Th}$ and ${ }^{40} \mathrm{~K}$ in Bq.kg-1, respectively. In order to keep the radiation hazard insignificant, the value of external hazard index must not exceed the limit of unity. The maximum value of $\mathrm{H}_{\mathrm{ex}}$ equal to unity corresponds to the upper limit of radium equivalent activity $370 \mathrm{~Bq} \cdot \mathrm{kg}^{-1}$ [18].

\subsubsection{The Representative level index (Iyr)}

This index can be used to estimate the level of $\gamma$-radiation hazard associated with the natural radionuclides. The 
radiation level index may be defined as [19].

$$
\mathrm{I}_{\gamma \mathrm{r}}=\mathrm{A}_{\mathrm{Ra}} / 150+\mathrm{A}_{\mathrm{Th}} / 100+\mathrm{A}_{\mathrm{K}} / 1500
$$

Where $A_{\text {Ra }}, A_{T h}$ and $A_{K}$ are the activity concentration of ${ }^{226} \mathrm{Ra},{ }^{232} \mathrm{Th}$ and ${ }^{40} \mathrm{~K}$ in Bq.kg ${ }^{-1}$, respectively. $\mathrm{I}_{\mathrm{yr}}$ May be used to estimate the level of gamma radiation hazard associated with natural radionuclides in the investigated soil sample.

All the calculated health hazard parameters are gathered and displayed in Table (4).

Table 4. The radium equivalent $\left(R a_{e q}\right)$, the external hazard index $\left(H_{e x}\right)$, the representative level index $\left(I_{Y_{r}}\right)$, the absorbed dose rate $(D)$ in $n G y / h$ and annual effective dose equivalent (AEDE) outdoor in $\mu S v y^{-1}$ for the studied samples.

\begin{tabular}{llllll}
\hline $\begin{array}{l}\text { Sample } \\
\text { No. }\end{array}$ & $\begin{array}{l}\mathbf{R a}_{\mathbf{e q}} \\
\mathbf{( B q} / \mathbf{k g})\end{array}$ & $\mathbf{H}_{\mathbf{e x}}$ & $\mathbf{I}_{\mathbf{\gamma r}}$ & $\begin{array}{l}\text { Absorbed } \\
\text { dose rate } \\
\mathbf{n G y}^{-\mathbf{1}}\end{array}$ & $\begin{array}{l}\text { AEDE } \\
\text { (outdoor) } \boldsymbol{\mu S V}_{\mathbf{y e a r}^{-1}}\end{array}$ \\
\hline Sh-1 & 121.92 & 0.33 & 0.86 & 55.74 & 68.36 \\
Sh-2 & 151.34 & 0.41 & 1.06 & 69.16 & 84.82 \\
Sh-3 & 201.00 & 0.54 & 1.41 & 91.34 & 112.02 \\
Sh-4 & 173.74 & 0.47 & 1.23 & 79.60 & 97.62 \\
Sh-5 & 210.97 & 0.57 & 1.49 & 96.49 & 118.34 \\
Sh-6 & 243.13 & 0.66 & 1.71 & 110.89 & 135.99 \\
Sh-7 & 215.30 & 0.58 & 1.52 & 98.52 & 120.82 \\
Sh-8 & 207.42 & 0.56 & 1.47 & 95.15 & 116.69 \\
Sh-9 & 287.46 & 0.78 & 2.02 & 131.36 & 161.10 \\
Sh-10 & 243.38 & 0.66 & 1.71 & 111.18 & 136.36 \\
Sh-11 & 455.35 & 1.23 & 3.15 & 205.60 & 252.15 \\
Sh-12 & 261.68 & 0.71 & 1.84 & 119.44 & 146.49 \\
Sh-13 & 257.17 & 0.69 & 1.78 & 116.05 & 142.32 \\
Sh-14 & 193.70 & 0.52 & 1.36 & 88.31 & 108.30 \\
Sh-15 & 265.00 & 0.72 & 1.86 & 120.71 & 148.04 \\
Sh-16 & 273.01 & 0.74 & 1.91 & 124.26 & 152.39 \\
Sh-17 & 362.83 & 0.98 & 2.54 & 165.30 & 202.72 \\
Sh-18 & 517.64 & 1.40 & 3.57 & 233.45 & 286.30 \\
Sh-19 & 350.25 & 0.95 & 2.42 & 158.34 & 194.19 \\
Sh-20 & 261.05 & 0.71 & 1.82 & 118.63 & 145.49 \\
average & 262.67 & 0.71 & 1.84 & 119.48 & 146.53 \\
\hline & & & & & \\
\hline & & & & \\
\hline
\end{tabular}

As shown in Table (4), the estimated absorbed dose rates based on soil radioactivity are ranged from 55.74 to 233.45 nGy.h $\mathrm{h}^{-1}$ with a mean value $119.48 \mathrm{nGy} \cdot \mathrm{h}^{-1}$. This mean value is higher than the worldwide mean value of $58 \mathrm{nGy} / \mathrm{h}$ [20].

The effective dose for the different locations varied from 68.36 to $286.3 \mu \mathrm{Sv}^{-\mathrm{y}^{-1}}$, with the mean value of $146.53 \mu \mathrm{Sv}^{-\mathrm{y}^{-}}$ 1 , which is higher than the worldwide effective dose of $70 \mu \mathrm{Sv}^{-1} \mathrm{y}^{-1}[21]$.

The values of $\mathrm{Ra}_{\mathrm{eq}}$ are ranged from 121.92 to 517.64 Bq.kg-1 with an overall mean of 262.67 Bq. $\mathrm{kg}^{-1}$. It can be seen that the $\mathrm{Ra}_{\mathrm{eq}}$ values for all soil samples in the present work (with the exception of the values associated with samples no.Sh-11and Sh-18) are lower than the accepted safety limit value of 370 Bq. $\mathrm{kg}^{-1}$ [22].

The calculated values of the external hazard index for all soil samples vary from 0.33 to 1.4 where the average value were found to be 0.71 . The results show that the $\mathrm{H}_{\mathrm{ex}}$ values for all soil samples (with the exception of the values associated with samples no.Sh-11and Sh-18) are below the limit of unity. This result means that the radiation dose is below the permissible limit of $1 \mathrm{mSv} \cdot \mathrm{y}^{-1}$ recommended by ICRP [23]. It can be concluded that the radiological health risks to the people living in the studied area is significant at certain zones.

Furthermore, $I_{\gamma r}$ for most samples is greater than unity which indicates that Nugrus area represents to some extent hazardous area that needs special precautions in establishing any trials to extract or explore the existing important elements.

\section{Conclusion}

The present work is devoted to investigate the health hazards of the environmental rock and soil samples from Abu Rusheid area in south eastern desert of Egypt using $\gamma$-ray spectroscopy and XRF techniques. As a consequence, the activity concentration of ${ }^{226} \mathrm{Ra},{ }^{232} \mathrm{Th},{ }^{40} \mathrm{~K}$ in the collected samples were evaluated. The absorbed dose rate, the radium equivalent, the external health hazard, the representative gamma index and the annual effective dose were also estimated and found to represent a significant radiological health hazard to people living in the investigated area. Therefore, safety rules and precautions should be applied for those workers in these fields. Also, the obtained results can serve as a radioactivity database for persons working in mining and milling activity in Abu -Rusheid area. Additionally, the samples were described by X-ray fluorescence and the obtained results prove that the majority of the samples contain considerable strategic elements concentrations such as $\mathrm{Al}, \mathrm{Fe}, \mathrm{Mn}$ and $\mathrm{Zn}$ that have considerable values in the advanced industrial domain.

\section{Acknowledgement}

Authors would like to cordially thank all the members of the nuclear physics group in the Physics Department, Faculty of Science, Ain-Shams University, Cairo, Egypt for their help.

\section{References}

[1] N. K. Ahmed, A. M. El Arabi, H. M. Mahmoud, and K. Salahel-din, "Measurement of natural radioactivity and its significant hazards of some hematite samples in Eastern Desert, Egypt," Build. Environ., vol. 42, no. 6, pp. 2263-2267, 2007.

[2] A. Sroor, S. M. El-Bahi, F. Ahmed, and A. S. Abdel-Haleem, "Natural radioactivity and radon exhalation rate of soil in southern Egypt," Appl. Radiat. Isot., vol. 55, no. 6, pp. 873$879,2001$.

[3] P. Chiozzi, V. Pasquale, and M. Verdoya, "Naturally occurring radioactivity at the Alps-Apennines transition," Radiat. Meas., vol. 35, no. 2, pp. 147-154, 2002.

[4] T. E. Myrick, B. A. Berven, and F. F. Haywood, "Determination of Concentrations of Selected Radionuclides in Surface Soil in the US.," Health Phys., vol. 45, no. 3, pp. 631-642, 1983. 
[5] A. A. Abdel-Razek, Y. A.; Bakhit, A F;Nada, "Measurements of the Natural Radioactivity along Wadi Nugrus, Egypt," Radiat. Phys. Prot. Conf., no. November, pp. 15-19, 2008.

[6] F. Adams, K. Janssens, and A. Snigirev, "Microscopic X-ray fluorescence analysis and related methods with laboratory and synchrotron radiation sources," J. Anal. At. Spectrom., vol. 13, no. 5, pp. 319-331, 1998.

[7] O. A. A. Eletta, "Determination of some trace metal levels in Asa river using AAS and XRF techniques," Int. J. Phys. Sci., vol. 2, no. 3, pp. 56-60, 2007.

[8] N. Ibrahim, "Natural activities of $238 \mathrm{U}, 232 \mathrm{Th}$ and $40 \mathrm{~K}$ in building materials," J. Environ. Radioact., vol. 43, no. 3, pp. 255-258, 1999.

[9] Unscear report, "Sources and Effects of Ionizing radiation," 1993.

[10] I. F. Al-Hamarneh and M. I. Awadallah, "Soil radioactivity levels and radiation hazard assessment in the highlands of northern Jordan," Radiat. Meas., vol. 44, no. 1, pp. 102-110, 2009.

[11] M. Tzortzis, "Determination of thorium, uranium and potassium elemental concentrations in surface soils in Cyprus," J. Environ. Radioact. J. Environ. Radioact., vol. 77, no. 3, pp. 325-338, 2004.

[12] M. Bashir, I. Ibeanu, Y. Zakari, and U. Sadiq, "Assessment of Radiological Risk in Flooded Soil Samples of Kudenda, Kaduna State Nigeria," Int. J. Eng. Sci. Inven., pp. 69-74, 2013.

[13] Unscear report, "Exposures from natural radiation sources," 2000.

[14] N. Damla, U. Cevik, A. I. Kobya, A. Celik, N. Celik, and R. Van Grieken, "Radiation dose estimation and mass attenuation coefficients of cement samples used in Turkey," J. Hazard. Mater., vol. 176, no. 1-3, pp. 644-649, 2010.
[15] H. M. Diab, S. A. Nouh, A. Hamdy, and S. A. El-Fiki, "Evaluation of natural radioactivity in a cultivated area around a fertilizer factory," J Nucl Radiat Phys, vol. 3, no. 1, pp. 5362, 2008.

[16] M. Tufail, T. Hamid, and others, "Natural radioactivity hazards of building bricks fabricated from saline soil of two districts of Pakistan," J. Radiol. Prot., vol. 27, no. 4, p. 481, 2007.

[17] R. Krieger, "Radioactivity of construction materials," Betonw. Fert. Techn, vol. 47, p. 468, 1981.

[18] S. Turhan and L. Gunduz, "Determination of specific activity of ${ }^{226} \mathrm{Ra},{ }^{232} \mathrm{Th}$ and ${ }^{40} \mathrm{~K}$ for assessment of radiation hazards from Turkish pumice samples," J. Environ. Radioact. $J$. Environ. Radioact., vol. 99, no. 2, pp. 332-342, 2008.

[19] A. A. Kinsara, E. I. Shabana, and M. T. Qutub, "Natural radioactivity in some building materials originating from a high background radiation area," Int. J. Innov. Educ. Res., vol. 2, no. 6, pp. 70-78, 2014.

[20] European Commission, "Radiological Protection Principles concerning the Natural Radioactivity of Building Materials," 1999.

[21] Y. Örgün, N. Altinsoy, S. Y. Sahin, Y. Güngör, A. H. Gültekin, G. Karahan, and Z. Karacik, "Natural and anthropogenic radionuclides in rocks and beach sands from Ezine region (Canakkale), Western Anatolia, Turkey," Appl. Radiat. Isot., vol. 65, no. 6, pp. 739-747, 2007.

[22] M. Belivermis, Onder Kihc, Y. Çotuk, and S. Topcuoglu, "The effects of physicochemical properties on gamma emitting natural radionuclide levels in the soil profile of Istanbul," Environ. Monit. Assess., vol. 163, no. 1-4, pp. 15-26, 2010.

[23] U. N. S. C. on the Effects of Atomic Radiation, Sources and effects of ionizing radiation: sources, vol. 1. United Nations Publications, 2000. 